\title{
Fragmentation versus Unity of the World Economy ${ }^{\#}$
}

\section{Pavel Neumann*}

Excluding the world bipolar structure and a special role of the centrally planned economies bloc before 1990, the post-war development of the world economy was directed to polycentric arrangement with its key building stones especially represented by so called "triad". The triad consisted of the most powerful or economically most developed subjects of the post-war structure, building up their prosperity on various forms of market economy. These were the countries or regions directly strengthened by their victory in World War II or, on the contrary, those defeated and destroyed by the War that restored their power only as a result of the post-war reconstruction. Approximately in 1960s the triad was definitely established in the following shape:

- U.S.A., and the North American region,

- Western Europe, with its core in EC/EU integration,

- Japan and the East Asia.

Despite the fact that the triad had already implicitly involved some elements of regionalism, in the post-war period a stronger accent was still laid rather on the role of national states (approximately till 1970s). This statement is valid in spite of the first appearance of the Western European integration, predetermining the future transition to the higher form of supranational regulation; nevertheless, that process was only at its preliminary stadium then. Sovereignty was still a significant feature of the states functioning and, therefore, the states were prepared and able to prevent their national economic interests against their competitors.

That attitude was also motivated by the ruling economic doctrine (Keynesianism, Neo-keynesianism) emphasising economic growth and full employment within national economies. Therefore, in that period the fragmentation was stressed especially on national levels and elements of regionalism were relatively minimal.

With respect to the role of Europe, East Asia and America, this article aims to analyze the post-war changes in the world economy fragmentation or unification in the context of multilateral or regional liberalisation practice. Additionally, some theoretical attempts are presented to explain the fragmentation-unity scheme.

Article has been worked out within the framework of the Czech Science Agency Project "Regionalism and multilateralism: foundations of the new world trade order?" No. 402/07/0253, and the Research Plan of the Faculty of International Relations "Governance in context of globalised economy and society" No MSM 6138439909.

* Doc. PhDr. Pavel Neumann, Ph.D. - Associated Professor, Department of the World Economy, Faculty of International Relations, University of Economics, Prague; nám. W. Churchilla 4, 13067 Praha 3, Czech Republic; $<$ neumann@vse.cz>. 


\section{Fragmentation and unity dilemma}

The post-war fragmentation of the world economy was gradually eroded by the escalating globalization trends, which built the base of economic activities beyond the level of national states. In addition, structural crises that broke out in 1970 s became the engine of globalization. The crises solution opposed the existing world economy framework characterized by its relatively closed national economies. Implementing the structural changes the states were pushed to open their economies more intensively, exposing themselves to international competition. Under the new conditions, the Keynesian economic policy also wrecked unable to drive a range of national economies through the crisis.

The running globalization brought a strengthened move of goods and investment in the world economy. One of the factors enabling the release of the investment and trade flows was the beginning of Neo-conservative wave in the economic theory and practice which, according to some authors, was closely linked with the globalization progress as well as the Keynesian doctrine failure (Girvan, 1999). The Neo-conservatism drive, pushing both a reduction of domestic regulation and free trade idea without any interstate barriers, confirmed definitely a liberalisation trend rejecting the previous forms of protectionism and relatively closed national economies in the post-war period.

After the War the trade liberalisation was dominantly performed as a multilateral process based on the GATT (later WTO) functioning. Multilateralism assumes the gradual integration of all potential trade partners into the process of the trade liberalisation (today particularly member states of the WTO). The multilateral approach as a base for the negotiation of the countries involved respects fully the attitude of all the participants, and trade liberalisation runs on the principles of reciprocity and non-discrimination.

Accordingly, the period culminating in 1980s (approximately in the initial phase of the Uruguay Round of the GATT negotiation) can be characterised as a phase of relative homogenisation in the process of globalization. In that period trade barriers were diminished mostly on the multilateral basis with the aim to achieve a form of unity within the multilateral order. In its main features that development followed the Neo-classical pattern of economic integration, according to which free or liberalised (multilateral) trade itself is the main form of economic integration (Haberler, 1964, p. 1). Similarly, that development also confirmed the fundamental neo-classical idea of a positive contribution of the global world integration.

Since there had not been any really significant creation of the international trade bloc systems until the late 1980s (with the exception of ES/EU), the rate of the trade regionalisation was relatively low. Therefore, the rate of the world economy formal fragmentation can be considered lower, or the rate of its unity (homogeneity) higher.

At the turn of the 1980s and 1990s the globalization process entered a new phase. At that time the double-dealing character of globalization became marked (Cihelková Neumann, 2002, pp. 29-54). Parallelly with the globalization and multilateralism process which is a homogenisation factor of the world economy, a tendency to fragmentation and differentiation appeared at the greater extent and led to the world economy disintegration into smaller economic units. The escalating regionalism became a symptom of the fragmentation. Naturally, the regional tendencies in the world economy are not exceptional even in the post-war period. However, entering its new phase in 1990s and at the beginning of the new millennium which is connected both with a growing number and a quality change of regional agreements, that regional wave is characterised as a "new regionalism" (Bhagwati, 1993). 
The outset of a new period can pose a question if the world economy goes on unifying, or if it becomes more fragmented. The fragmentation versus unification dilemma is derived from several theses often mentioned, often mutually controversial which are cited in connection with the regionalism emerging in the world economy:

- In comparison with the unilateral non-preferential liberalisation, regional integration can be more attractive for many countries. It namely provides individual countries with an easier access to the selected markets of their partners. Reciprocal preferences are provided between partners as well as protection from international competition increase is guaranteed. Liberalisation based on the preferential or regional principle is easier for many countries than the multilateral approach. For this reason, selected countries start the liberalisation right through joining the regional integration and keep preferring it even later.

- Regional trade agreements (RTAs) become more important with escalating problems within the General Agreement on Tariffs and Trade or World Trade Organisation (GATT/WTO) negotiations. These negotiations cannot solve the trade issues in their complexity (Baldwin, 1993). The more complicated the multilateral negotiations will be or if they fail, the more intensive regionalism growth will be (Kol, 1995, p. 25).

- RTAs and the strengthening regionalism are not in harmony with the elementary principles of WTO, if they cause non-member states discrimination as well as the significant trade system fragmentation as a result of permanent and fast growth of new free trade areas (Bhagwati - Panagariya, 2003).

- RTAs need not be a threat to the multilateral trade system if, according to the WTO rules; their internal liberalisation is not accompanied by increasing protectionism (Kol, 1995, p. 25) on the outside or if they rather liberalise their trade towards the third countries, i.e. they keep the form of open regionalism (Cihelková - Neumann, 2002, pp. 31-33).

- Regional trade still provides net trade creation and increases welfare of the world (Burfisher - Robinson - Thierfelder, 2003, pp. 11-13).

Based on 1990s development when the RTA number increased remarkably, a hypothesis can be formed that the world economy is formally more fragmented. However, that fragmentation is double-in-one process because of its running within globalization, or global liberalisation, which involves multilateral negotiation on trade liberalisation. At the same time, the formal fragmentation being a natural element of that process can temporally complicate global liberalisation; nevertheless in the long-term horizon it serves mostly as a supporting factor of liberalisation.

The following analysis aims to explain the hypothesis with respect to both theoretical resources of liberalism and regional and global integration/fragmentation course.

\section{Theoretical basis of the concept of regional liberalisation as potential fragmentation}

Since the middle of $20^{\text {th }}$ century the theoretical perception of the world economy regionalisation, or RTA origin, which can cause the world economy fragmentation, has passed through several phases (Rieder, 2006, pp. 5-6).

The theory elements were laid by Jacob Viner as early as in 1950 (Viner, 1950). Viner brought a basic characteristic of RTA classifying the main benefits and negative con- 
sequences of the trade agreements existence. In his opinion, RTAs lead to trade creation on the one hand, which refers to the increase of the trade among the members of an RTA thanks to the elimination of the trade barriers. On the other hand, however, they may lead to trade diversion, by which non-member states are afflicted. The trade diversion is caused by the trade barrier increase which makes the position of a low-cost outside supplier harder and, on the contrary, which makes the position of a less efficient regional partner more advantageous.

Looking back to Viner's theory, we can see that the debate on trade efficiency was confined to the static level in this case, or RTA membership expansion was treated as exogenous.

Significant changes in the theory were brought just with the new regionalism wave mentioned above, which began to think about regionalism as a dynamic process. A new pattern of RTA perception was worked out in Baldwin's domino theory of regionalism (Baldwin, 1993). Baldwin introduced the first formal model to analyse the implications of the trade diversion for membership in a particular RTA.

The theory contains a basic assumption that national trade policies are endogenous in principle (Rieder, 2006, p. 5). They namely results from equilibrium between the demand for the economy protection and its supply. The governmental policy of the particular states balances the pressure of the domestic lobby (i.e. firms exporting to RTA) on membership in a trade bloc with anti-membership forces.

If a new RTA is concluded or the existing one deepened, a loss of competitiveness and lower profits for non-member firms exporting to RTA can lead the firms to intervention in government policy. As a result of that pressure the equilibrium of the economy protection changes and the states will join the RTA. This enlargement of the bloc increases the costs for the non-members as the number of rivals with the preferential market access has grown. Consequently, a new pressure arises to repeat the whole cycle with other countries. Thus, regionalism is spread as a domino effect, if the RTAs in question are open and any country requesting for membership is admitted ${ }^{1}$.

Baldwin's basic framework has been completed by several authors focusing on the difference between open customs unions and unions with exclusive membership. In their opinion, the open blocs are the stepping stones of the global free trade, while the exclusive ones may become its stumbling blocks (Yi, 1996, pp. 153-177). Other authors have summarised the relation between the global free trade and bilateral or regional groups. They show that the global free trade is a unique equilibrium outcome if the aggregate welfare under the global free trade existence is higher than under the existence of any combination of bilateral and regional trade agreements (Aghion - Antrás - Helpman, 2004) ${ }^{2}$.

From another point of view, the theoretical approaches dealing with regionalism (or world economy fragmentation) can be distinguished with respect to its ,"new “ and "old“ development level (Burfisher - Robinson - Thierfelder, 2003, pp. 2-3). The phase until 1980s was represented as an „old“ regionalism characterised mostly by shallow integration (with the exception of EC/EU) eliminating especially barriers to the trade in commodities. The "new" regionalism involves distinctive elements of deeper integration exceeding standard protection policy, and is directed to broader integration links between developing and developed countries.

1 Baldwin mentions the „perfectly elastic supply of membership“as a membership precondition. (Baldwin, 1993, p. 29).

2 If the aggregate welfare under global free trade is lower than under a system with bilateral and regional trade agreements, global free trade may only occur under particular circumstances as presence of trade diversion. 
In accordance with the old regionalism level, its theoretical analysis was concentrated on the theory of customs union, commodity trade effects in the countries within a RTA (trade creation) and between the RTA and the rest of the world (trade diversion) as well as terms-of trade-effects. On the contrary, developing the deep integration the new regionalism represents the new quality which involves liberalisation of investment, labour, technologies and knowledge moves; harmonisation of economic policies up to a monetary union as well as harmonisation of taxes and other subsidies; in addition various types of institutions regulating the integration are established. Accordingly, the theory is directed to examining new aspects of the integration participants mutual relations, such as productivity changes linked with integration relations (i.e. ,new growth theory“), imperfect competition issues, rent seeking behaviour, lobbying, etc.

With respect to the new regionalism, undoubtedly, the new trade theory is able to touch a wide range of issues. In its effort to explain the complex links between the regional and multilateral liberalisation the theory development probably reflects the growing formal fragmentation of the world economy. However, some authors note that the theoretical analyses are relatively incoherent and eclectic in comparison with the"elegant" Viner-Meade or Heckscher-Ohlin-Samuelson model (Burfisher - Robinson - Thierfelder, 2003, p. 20).

\section{World economy unity and fragmentation: the role of particular centres}

As mentioned above, the world centres formation, or later regional economic integration, caused the tendency of the world economy fragmentation into three coherent parts. At least until 1990s, or probably even later, the growing concentration on internal trade (intratrade) as a fragmentation feature was more significant only in Europe (Kol, 1995, p. 25). In the period from1964 to1987 the share of intraregional import of the OECD European countries in their total share increased from $56.4 \%$ to $69 \%$. That indicator also markedly grew up in Asian countries (from 20\% to 41\% in 1964-1988); nevertheless, compared to Europe the intratrade share was lower. Similarly, the indicator fell behind in the North-American region where it fell down to $27.5 \%$ from its peak rate in 1969 (40.5\%).

The trends mentioned were explained as a result of the continuing multilateral trade liberalisation, which had run successfully at least to the mid 1980s and offset the regional integration trend. (Kol, 1995, pp. 28-29).

\subsection{Europe}

The economic regionalisation process began particularly in Europe, which can be considered a notable region with the top level of integration in a long-term horizon. After World War II, European integration and regionalisation went through a permanent development both qualitative, aiming at deepening the integration towards a higher integration level, and quantitative (enlargement, or making a new structure of the integration bloc member states).

In the case of Europe special reasons for deep integration are pointed out as European motives are not only economic but also to the great extent political. Undoubtedly in Europe there was a strong effort to get over a huge economic and political fragmentation as a barrier of establishing necessary European stability. In comparison with the other centres this objective was quite urgent here (Cihelková - Neumann, 2002, p. 39) and represented a strong integration motive. 
The Western Europe regional integration process developing from the beginning of the 1950s gradually set an objective in that segment to create closer regional links in the shape of a common market presuming free movement of goods, services, investment and labour. Western Europe had taken crucial steps in that direction already by the beginning of 1980s, before passing the plan to complete the Single European Market. The integration trend was proved by large institutionalisation of integration accompanied by intraregional trade and investment growth as well as by the first common policies development.

At its beginning the Western European integration process itself proceeded in an internally differentiated way. By 1960 two integration groups were created. The European Economic Community (EEC), or later the European Community (EC), soon exceeded the level of a sole trade links represented by the customs union (1968) and aimed over the common market formation at building an economic and political union. That process was accompanied by a supranational character of the integration. On the contrary, the less ambitious European Free Trade Association (EFTA) remained in the lower phase of integration declared as a free trade area. By the gradual diminishing of the member states number in favour of the EU caused by greater attractiveness of the main integration stream, EFTA has lost its economic importance though.

In its effort to build a monetary union the European Union is a typical example of deep integration representing the most advanced type of regionalism on the world scale. Since 1990s the EU development has opened a possible but not certain perspective of its political integration based on a federation or confederation principle. It is to strengthen the role of those EU institutions which defend all-European interests. Recently some steps in that direction have been also considered in a discussion on European Constitution. In spite of the fact that such a political shift is not likely nowadays, in the political area it represents a vision intensifying regional integration. Concerning the political integration it should be mentioned that the EU follows its own geo-strategical interests in relation to the other regions.

Similarly, the political integration stems from the European centre enlargement as well as from the changes within its both parts. On the one hand, the integration completes the transformation process of the Middle and East European countries. On the other hand, the structural adaptation of the Western Europe comes to its end. Accordingly, the Eastern part transformation was formally completed in 2004-2007 by the full membership of the candidate states which requested the previous adjustment of the "old" EU. From the very beginning the whole process can be considered a European adaptation to the evolving global economy of multiple regional centres (Schwartz - Zysman, 1998).

Economically, the ES/EU aimed at creating a relatively homogeneous structure, which is also determined by a convergence rules system as an axis of the European integration. The way was initially enabled by minor differences in the member states economic indicators. Later however, the EU had to overcome increasing heterogeneity arising after its South enlargement and especially after the access of the Middle East European countries.

The „new heterogeneity“ after 2004 is a change in comparison with the traditional EU internal market which was relatively homogeneous and enabled the European intratrade to expand and deeply link the original national markets. Already before the new states entry, the questions were put forward if and how the existing market and regional competition (Schwartz - Zysman, 1998) or the EU world position could be affected by the new heterogeneous structure.

Undoubtedly, the EU enlargement will have different consequences for the regional integration. The EU heterogeneity growth implies the decrease of its average economic le- 
vel (GDP per capita, etc.). However, the additional countries will be involved into a relatively deep structure of the regional economic integration such as the common market or monetary and economic union in the future. Those countries integration process is not considered easy, nevertheless, consequently it could bring stimuli which are expected from the regional integration (Hilaire - Yang, 2003, pp. 9-10), namely in Europe on a wider scale than in other centres.

Now the EU represents a much diversified group involving highly complementary partners in its basic pattern. The lower economic level of some EU parts would lead, in accordance with the EU goals, to the development of quantitative and qualitative stimuli both for weak (less advanced) and strong EU countries. Along with the large common market in principle eliminating the barriers of the movement of the most production factors as well as production results among a big number of states it could mean the further step towards strengthening the EU competitiveness including its position in the world economy.

At first, from the regionalism and fragmentation theory point of view the regional bloc in Europe is characterised by the growth of trade creation in the long-term period. In this way the European RTA coefficients were interpreted after RTAs establishing in 1951-1967; at the same time the trade creation effect was substantially larger at the EEC

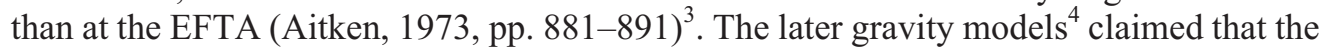
countries, members of the same RTA, trade with each other more than would be expected with respect to their economic conditions.

The countries joining the EC in 1980s experienced a $68 \%$ increase in trade with the other member states by 1990 , while the EFTA countries didn't find any significant trade creating effect (Frankel - Wei, 1993). Later, the research started to explain dynamic effects of regionalism. The impact of the regionalism domino effect in Western Europe was examined (Sapir, 2001, pp. 377-388). The research found supporting evidence that the domino effect played an important role in several rounds of the EC/EU enlargement. Similarly, it was proved that while EFTA countered successfully the EC/EU competitive integration until the mid-1970s, the leaving of Great Britain and Denmark together with the EC common market preparation had a negative impact on EFTA and. this impact sped up the further EFTA members' application for the EC membership, too.

Generally, based on the research of R. Rieder for 1962-2004 period (Rieder, 2006), we can conclude that the EC/EU existence had a strong influence on trade processes not only in Europe but also within a wide framework of the OECD countries. The existence of both trade creation and diversion was proved. The EU intratrade was by $35 \%$ higher in average throughout the period than its non preferential trade. On the contrary, the export from non-member states to the EU was by $10 \%$ lower than their export directed out of the integration. The fact refers to the importance of the trade diversion caused by the EU development.

At the same time, it also refers to the fact that the forming of the EU trade bloc strengthened the countries being out of the bloc in their decision to apply for entrance; thus the definitive turn was stimulated during the domino effect. Parallelly, the effect was enhanced by an additional factor (such as trade uncertainty and troubles within WTO multilateral negotiation), or suppressed (ambiguous impacts of the high EU institutionalisation on the candidate states decision to join the integration) (Rieder, 2006, p. 33).

3 These coefficients serves for estimation of the factor, which caused the intratrade increase within RTA as a result of the EEC and EFTA forming.

4 The gravity models of international trade assume that the bilateral trade volume can be estimated as an increasing function of the sizes of the trading economies, and a decreasing function of their geographic distance. (Wall, 2002, p. 29). 


\subsection{Asia (with the Accent on the Eastern Part)}

In the previous decade some working papers dealing with the regional integration attributed a relatively small integration potential to the East Asia due to the lower growth of regional intratrade. While in Europe they stated a rapid increase of internal trade concentration, it was less distinctively seen in the North American region and even very underestimated in Asia (Kol, 1995, p. 25). That tendency was a characteristic feature still in 1980s. A contingent intratrade increase was attributed rather to the trade growth of the East Asia countries as a whole than to the discrimination of the third states in their access to Asian markets. That trend was in contrast with the real or potential development in the Western Europe as well as in the North America.

In spite of the total Asian trade doubling in 1980s (especially thanks to the exchange with the North American markets), Asia remained the only region where the relative share of the intraregional trade had not changed roughly in comparison with the total exports (34\% in $1980-35 \%$ in 1989 (Kol, 1995, p. 25)). At the same time, the general outward orientation of the region was proved, especially towards the U.S.A.

Those facts led to the opinion that there was a low interest in forming a regional bloc. The opinion also reflected the economic integration stagnation of ASEAN, the most significant group in the East Asia in that decade. The dependence on non-Asian markets was strengthened. The extraordinary economic performance of both new industrialised countries (NIC) of Asia and Japan was considered a result of a smooth trade access to the West European or American area, especially as far as manufactured output is concerned. The low degree of the regional trade concentration or stagnating integration was also connected with relatively smooth continuance of multilateral liberalisation; nevertheless, even its possible failure would not be unambiguously presented as a reason for the potential regional integration development either.

Among the reasons for that outward orientation can be also ranged other Asian specific features. The Asian region is considered very heterogeneous both in the economic and political sense while in some authors' opinion the economic heterogeneity was being rather entrenched in the late 1990s (Schwartz - Zysman, 1998). The countries structure is rather complementary in the region especially with respect to the high differences between raw material and capital equipment. In the past, unlike Europe, the high military rivalry existing in the region obstructed political and economic unifying. At least until 1990s there was a very reserved attitude of a number of NIC towards the potential key economic partner, Japan, which had been balanced to a considerable extent by economic contacts with the U.S.A. and Europe 5 .

Based on those facts, in the early 1990s the interests of a broader Asia-Pacific region were seen especially in an open global trade system (Panagariya, 1994, pp. 16-19).

In the course of 1990s and nowadays a certain shift can be seen in the real East Asia integration as well as in its evaluation. Naturally, some original regional characteristics keep their validity as a sign of outlasting specific features; nevertheless, the region has probably come closer to the global regionalisation trend. The East Asia characteristics can be demonstrated on the ASEAN integration and on several further countries aspiring to a closer alliance with that group.

5 Though the trade of East Asia countries with Japan increased rapidly, the Japan trade itself accelerated more significantly with North America and Europe (with the exception of China). (Kol, 1995, p. 31). 
Following the gradual release of international tension and world bipolarity disappearance the stress in ASEAN integration was transferred significantly into the economic area. ASEAN started the process of closer integration in 1992 when the decision was made to complete the free trade area of the ASEAN states (AFTA) by 2007. The decision followed a dramatic increase of regional trade agreements in the world. The regional integration growth represented a marked world phenomenon ${ }^{6}$.

The trend encouraged a response in the East Asia area, too. On the one hand, it was manifested by the enlargement of the member states base when some less developed countries entered the ASEAN in 1995-1997. At the same time more profound integration changes occurred gradually, such as attempts to deepen the existing integration forms beyond the free market frame and to form a broader regional group, which would enable ASEAN to join all the important countries of the area through various types of formal integration or economic co-operation.

There have been various reasons for the strengthened integration since the mid 1990s (East Asia Economic Community: Prospects and Implications, 2003). At first, the East Asia countries went through a strong economic shock as a result of the Asian financial and economic crisis followed by serious recession in many countries. The crisis served as a catalyser of the further economic integration, which would prospectively reduce the region sensitivity to the similar economic instability in the future.

Secondly, the ASEAN countries felt dissatisfied with the liberalisation progress within the World Trade Organisation, or within Asia-Pacific Economic Co-operation $(\mathrm{APEC})^{7}$. Therefore, they inclined more towards removing economic barriers in a closer circle of the neighbouring states. The effort for closer integration within the East Asia region resulted in a bold integration goal to establish ASEAN Economic Community (AEC). Thus, at the beginning of the new millennium ASEAN even declared the aim to achieve gradually the integration level corresponding to the common market parameters.

However, due to the still existing barriers there is a low share of the mutual trade (intratrade) of ASEAN in its total trade exchange. It is true, that the exports aimed at the member countries have been growing faster than the total ones recently. For example, in 2002-2003 the growth amounted to $15.4 \%$; the mutual import increased slightly, too (ASEAN, 2004). Though the share of internal export as percentage of the total export has advanced, especially from the ASEAN establishment when it was about ten percent, nevertheless, in 2003 it kept amounting to $23.16 \%$ only. The internal import even slightly dropped representing $20.73 \%$ of total imports (ASEAN, 2004a).

Apparently, the tendency mentioned above has not changed significantly yet. The gravity model of the long-term trade development reviewing the period 1984-2005 (Tumbarello, 2007, p. 11). claims that as a result of the integration bloc membership, two ASEAN countries trade with one another 3.3 times more than one would expect given their economic size, geographic distance and character. However, during that period the members' mutual trade flows did not rise to the significant extent compared to the trade growth with non members. Thus, the trade between two ASEAN members is estimated to be by $38 \%$ less than their trade exchange directed out of the Association. Therefore, in ASEAN case as

6 If in period from 1948 to 1994 GATT registered 124 RTAs, WTO from its origin in 1995 to 2003 recorded the bigger number of new agreements than in the previous period (265 RTAs existed in 2003). (East Asia Economic Community: Prospects and Implications, 2003).

7 Some comments mention that the chance to realise the economic integration in the ASEAN framework is bigger than the one within APEC because ASEAN has a stronger will to build regional integration. In APEC political issues are being dealt more often now and generally the WTO negotiations are preferred in removing trade and investment barriers (Reyes, 2005). 
well as in other Asian integrations examined (APEC, SARTA) the trade diversion increase does not occur ${ }^{8}$.

The special character of integration is given by several historical factors, which have already been partly mentioned above. Above all, the development in East Asia in long-term horizon, partially at least in 1990, followed unilateral liberalisation, i.e. countries did not take a preferential approach towards their partners during trade liberalisation. This non-discriminative liberalisation is more characteristic for advanced Asian countries.

In addition, if it was running, the regional trade liberalisation proceeded in parallel with the multilateral liberalisation, or followed it. A lot of Asian countries joined WTO only in the mid 1990s, so the regional integration occurred already under the significant tariff decrease corresponding with the most favoured nation clause tariff. Therefore, the risk of the trade diversion rise was diminished in the arising RTAs. The rate of intratrade is also in accordance with that fact. Its certain level was already established before the regional integration development, and its progress has not been stimulated so strongly by further regional steps so far. To a certain extent the intratrade development could be affected by the group of least developed countries of ASEAN (Cambodia, Laos, Vietnam) which have or had high customs tariffs. In the light of this, the statement on trade diversion non-existence can be seen as problematic in ASEAN.

The greatest part of the ASEAN trade (nearly fifty percent of the total export and import) is still directed to the five biggest external trade partners (U.S.A., Japan, China, the EU, South Korea). Naturally, there is an assumption of intratrade growth to proceed. However, its current low share gives evidence that for the time being the internal trade liberalisation is completing only its first phase, and (also under the influence of permanent dependence on the traditional trade partners) is still far from the stage of the general liberalisation of mutual goods exchange. At the same time, in accordance with the tendencies mentioned above, ASEAN makes an effort to preserve the highly open economy of its member states towards all the third states interested in developing the mutual trade (ASEAN, 2004b). Therefore, the ASEAN development resulted in an open regional co-operation at the beginning of the new millennium. The example is formation of the East Asia Economic Community (EAEC) ${ }^{9}$.

The EAEC comes out of the idea of linking the existing free trade areas in a region with some other important economies in the area. Through the link a market of 2 billion consumers would come into existence. The countries involved would represent about $20 \%$ of the world GDP (6.3 trillion dollars) as well as $17 \%$ of the global trade with the volume of 2.2 trillion dollars. Besides the ASEAN, at least six countries take part in that structure $(A S E A N+6)^{10}$. Then the share of intratrade in the region as a whole is markedly higher than in ASEAN, for example. It increased from $28.4 \%$ in 1998 to $34.5 \%$ in 2001. Along with the completion of the free trade area between ASEAN and the other states, those trade flows become more important (East Asia Economic Community: Prospects and Implications, 2003).

8 The tendency is not clear at some countries which are parallelly the members of the other RTAs (Tumbarello, 2007, p. 10). Some other models mention partial trade diversion under ASEAN, especially with respect to import.

9 This vision was declared by Deputy of ASEAN General Secretary Pengiran Mashor Pengiran Ahmad at ASEAN+3 Session in Seoul, December 2003 (East Asia Economic Community: Prospects and Implications, 2003).

10 An open economic co-operation is at stake at the beginning which should gradually transform into the free trade area linking ASEAN with China, South Korea, Japan, Australia, New Zealand and India. 
Therefore, from the integration forms point of view the East Asia continue to be the example of open regionalism, having the high degree of free trade with the rest of the world in comparison with the other RTAs ${ }^{11}$. Its form is a substantially looser type of integration different from the arrangement in Europe (EU) as well as from the American region to a certain extent (NAFTA). The common market building up (as an analogy to the European Union) would represent a tedious and difficult process for the relatively heterogeneous East Asia area, the costs of which might not be adequate to benefits. Therefore, we can assume that the open regionalism, combining various forms of co-operation both inside and outside the region and completed with a continuous building of the wide free trade zones, represents the most acceptable shape of the East Asia economic integration in the present.

\subsection{The Americas}

The Americas represent a differentiated project of regional integration not very similar to Europe, especially with respect to the depth of the integration groups formed and to the absence of supranational bodies. The motivation for integration differs not only from the European area but also from Asia. In the case of the Americas the integration was stimulated by special interaction of hemispheric, sub-regional and multilateral processes (Phillips, 2003 , p. 2). In the long-term horizon the shape of integration is especially influenced by the United States as well as by their relations to other American partners. In spite of the attempts of Latin American states to form their own regional projects, finally the U.S.A. as a hegemony in the American area, asserts their firm positions. The United States choose especially those approaches, which enable them to prefer their complex interests.

At the beginning, the U.S. interests were concentrated on security solution as well as democracy spread in Latin America; only later were those activities "integrated" into broader economic projects. Thus, the trade agenda itself was seen as second-rate at first. The importance of economic interests, later leading to the effort to build a more advanced regional integration, however, increased especially as a result of the multilateral liberalisation progress weakening. Nowadays the U.S.A. are urging the implementation of a certain framework of trade discipline among the region countries, which, in addition to the free trade, would ensure obligatory rules in the range of mutual economic relations (intellectual property protection, government procurement, competition policy, investment, services, etc.) (Phillips, 2003, pp. 2-5).

Historically, the mode of regional integration forming stemmed from the U.S. attitude, or from the rate at which the existing liberalisation was able to meet the U.S. economic requirements. In the early post-war period the U.S. trade relations demonstrated a highly diversified model equally including Europe, Asia and America. That model strengthened namely the U.S. global position rather than the regional one (Fishlow - Haggard, 1992, p. 15). This was the question of unilateral liberalisation determining a more or less symmetric approach towards all partners. As a result of that tendency, followed by a range of other countries, the mechanism GATT/WTO was constituted, which became an instrument of multilateral liberalisation.

Nevertheless, later this shape of multilateralism did not enable the U.S. preferred areas of liberalisation to develop enough (e.g. services, investment). Thus, the multilateral platform was ineffective from the U.S. point of view if it did not ensure sufficient progress of liberalisation and preferred the interests of other states to the U.S. detriment, especially in the areas mentioned (Gruben - Welch, 1994, p. 35). In addition, also the impact of the domino

11 For example, under its integration influence NAFTA trades by $60 \%$ less with the rest of the world than it would be expected based on the standard gravity model. (Tumbarello, 2007, p. 13). 
effect mentioned above started to work strongly encouraged by the European integration development.

Therefore, since the late 1980 s the U.S.A. have taken recourse to the solutions different from the multilateral ones at the trade liberalisation, and they have started to form regional blocs. At first, they began the negotiations with Canada that were completed by signing an agreement on the free trade between both the countries (Canada-U.S. Free Trade Agreement). The later broader negotiation under Mexico's participation led to the signature of NAFTA (the North American Free Trade Agreement) in 1990s. The agreement markedly exceeded the framework of pure liberalisation of manufactured goods trade. In addition to the long-term liberalisation of the agricultural products trade, it also assumes the selective free movement of services and investment, as well as the high protection of intellectual property rights and application of the rules of the goods origin.

The creation of the free trade zone among the U.S.A., Canada and Mexico was taken as an experiment demonstrating to the other states of the American continent whether the free trade or higher levels of integration can bring positive effects, namely also to the less advanced countries. The NAFTA success could be a precedent either for other states accession or for another broader agreement conclusion on free trade area. Thus, the NAFTA was predestined to become a model example for the integration proceeding in the Western hemisphere up to the creation of NAFTA's all-American variant (Hansen-Kuhn, 2003). The inspiration of that first successful integration step led the U.S.A. to beginning concrete negotiations with other states aimed at forming the Free Trade Agreement of the Americas (FTAA).

The FTAA negotiation agenda consisted of nine groups. Similarly to NAFTA the FTAA was to contain a wide range of provisions exceeding the current liberalisation framework of the WTO: for example in the area of investment, intellectual rights protection, services, government procurement, competition policy. With respect to its quality (depth of integration measures) and quantity (the area including 800 million inhabitants and states creating GDP of over 13 billions USD) the FTAA should have belonged to the most ambitious integration projects of the present besides the EU. The attempt to establish the FTAA could have been a certain break-through on the American continent where the appearance of a new integration quality covering the majority of the hemisphere countries was expected at first; similarly also in the context of the relation of multilateral and regional liberalisation on the world scale.

Obviously, from the U.S. point of view the FTAA was to represent the arrangement called a WTO-plus (Phillips, 2003, p. 6). With respect to its results assumed, FTAA made an effort to go beyond the framework of the existing multilateral provisions approved by WTO. Naturally, the regional conditions were able to offer better opportunity in the areas mentioned above than the multilateral level. At the same time the proceeding regional negotiations could have brought more gains of liberalisation especially for the U.S.A., namely through implementation of the measures and rules which are desired and priorities for the country.

In addition the FTAA aimed at establishing a certain precedent, or negotiation break-through, which was to influence markedly the following negotiations both multilateral and regional outside the American area. In connection with the effort the U.S.A. presented new approaches to the world liberalisation process at the beginning of the new millennium. One of them is so called additive regionalism (Hilaire - Yang, 2003, p. 3). Within its framework agreements on free trade are concluded with major trade partners as a complement 
of the multilateral liberalisation. These agreements help to create a common negotiation procedure or compensate the slow progress of the multilateral process.

The strategy of competitive liberalisation also raised an extraordinary, though not unambiguous, response. This strategy was emphasised by the former U.S. trade representative R. Zoellick (Weintraub, 2003, p. 1) ${ }^{12}$, for example. In his opinion the U.S.A. should negotiate the decrease of the trade barriers on many platforms: bilateral, plurilateral, regional and global. Many countries encouraged by the fear of advantage loss if they remain out of the process will follow this strategy and thus they will compete with each other in the opening of their markets ${ }^{13}$. An example could be the NAFTA conclusion, where expected preferences on the American market will lead other countries of the Western hemisphere to create the wide all-American free trade area. Finally, the competitive liberalisation could lead to a single world free trade area (Andriamananjara, 2003, p. 2).

Based on the trends mentioned above supporting the rise of FTAA (especially thanks to the U.S. effort) some authors consider the FTAA to be an attempt to "regionalize" the multilateral process. If the regional negotiations conducted so far were the activities in compliance with the WTO rules, and as such marked as WTO-compatible, then FTAA could mean the beginning of the shift to the WTO-plus arrangement (Phillips, 2003, p. 6).

The United States and a group of other countries having or preparing a bilateral agreement with the U.S.A. have backed that "ambitious" variant covering the great number of integration areas mentioned. On the contrary, the MERCOSUR member states headed by Brazil opposed the U.S. ambitious mode of the FTAA and formulated rather moderate goals. Gradually those countries inclined to the opinion that the "sensitive" items (investment, services, intellectual property rights, etc.) should be excluded from the FTAA negotiation packet and left to WTO agenda. The step was reasoned by the fear of many countries that foreign investors, especially the U.S. ones, would gain a strong position in developing economies. Though the FTAA should have been concluded by 2005, the continuing disagreement among the participants led to the negotiations arresting.

The results so far achieved and further prospects of the American integration are not convincing, nor with respect to the trade creation and trade diversion. According to research studies neither NAFTA nor MERCOSUR implementation led to the trade creation. NAFTA was accompanied by the trade diversion, while the MERCOSUR results are ambiguous (Morais - Bender, 2006, p. 11). The individual countries do not follow that scheme though, and under certain circumstances they would not necessarily need to close their economies towards the rest of the world. Mexico, for example, opened its economy more already before joining NAFTA, which could have led to the trade creation but that trend was diminished or negated by Mexico's access to NAFTA. In the case of MERCOSUR imports from non-member states paradoxically increased as a result of a parallel opening to the world at the time of the MERCOSUR agreement signing. Then the impact on MERCOSUR is less unambiguous with respect to the import trade diversion, while the NAFTA results show a relatively coherent pattern of the trade diversion. In both the NAFTA and MERCOSUR cases export to non-member states has decreased. Thus, their member states foreign trade has become more regionalised. However, the trade diversion represents a special case here when a competitive importer is not necessarily replaced by a less competitive one (Morais - Bender, 2006, p. 11).

12 The term „competitive liberalisation“ was used in 1996 for the first time. (Bergsten, 1996).

13 R. Zoellick in its testimony before the U.S. Congress claimed that ,by advancing on multiple fronts, we are creating a competition in liberalisation“. (Peterson, 2003). 
The share of intra-regional trade on the total trade of the American area as a whole grew up significantly during $1990 \mathrm{~s}$ : from $48 \%$ to $61 \%$. The intratrade is relatively strong in the NAFTA framework, where it shared $55.5 \%$ of its total exports and $39.6 \%$ of imports. The data for MERCOSUR are different: both the intra-exports and imports of the group represent only $17-19 \%$ of total exports and imports; nevertheless the trade with North America is extraordinary high and relatively high also with Western Europe (Diao Díaz-Bonilla - Sherman, 2003, pp. 2-3). It proves the lasting relative opening, or the low rate of internal integration links among the Latin American countries.

Also some scenarios of potential effects of FTAA completion have been created (Diao - Díaz-Bonilla - Sherman, 2002, pp. 9-10). The models claim that the agreement implementation could bring a net trade creation (trade creation would greatly exceed trade diversion); the trade diversion itself would have relatively minor effects on the partners outside FTAA involved. At the same time the gains of trade are larger for the Latin American participants than for their big potential partners (the United States). These results are consistent with the earlier studies of NAFTA, which also predicted small integration impact on the U.S.A. and substantially large on Mexico.

\section{Conclusion}

From the outline given above it is obvious that the world economy have gradually changed its shape with respect to its structure.

Its original fragmented structure determined by individual national states relatively isolated by the political and economic development resulting from World War II gradually transformed into a new arrangement. In spite of some suggestions in the shape of regional centres created, until 1980 there was a relative unity of the world economy in the process of multilateral liberalisation reached through the wide spectrum of economic links (both trade and investment) as an accompanying feature of globalization. The individual economies action radius grew, namely that of the large ones and covered (especially in the U.S.A. case) widely all regions. The world economy was rather unified than fragmented by the system of the multilateral relations.

The turn was brought in the last phase of regionalisation culminating in 1990s. At that time as a result of prolonged problems in the GATT/WTO multilateral negotiations, the attraction of RTAs increased as they enabled a better access to the trade partners' markets and met the interests of the integrating countries better. Despite some voices presenting the regionalisation as a principal obstacle to multilateral liberalisation, the majority of authors incline to the thesis of a general benefit of RTAs which, if in accordance with the WTO rules, do not jeopardise further liberalisation and make net trade creation. Undoubtedly, the new regionalism escalates the formal fragmentation of the world economy; however, that fragmentation probably need not be necessarily the barrier in the creation of deeper relations leading to the world economy "unity".

Based on the tendencies mentioned above we can draw some conclusions on the dilemma of the world economy fragmentation and unity.

The European region went through certain fragmentation by dividing into several groups (EC/EU, EFTA, and the Eastern Europe bloc). Gradually the fragmentation was diminished thanks to centripetal forces drawing both EFTA states and the Middle and Eastern Europe countries to the main stream of EC/EU integration which has changed quantitatively as well as qualitatively as a result. Nevertheless, the European fragmentation proceeds as 
a differentiation or heterogeneity of the EU-27, encompassing the countries of different economic levels (even in comparison with EU-15)

Thus, the development of the European integration generates two effects, internal and external. On the one side, it creates impulses to the internal development of the member states, to their unifying under the integration rules which calculate on the increase of the EU economic cohesion, or getting over its internal fragmentation. The European area is potentially homogenised in this way. The development is the first result of the domino effect leading non-member states to access to integration with the aim to eliminate trade barriers. On the other side, the European processes themselves have significantly stimulated the domino effect influencing the rise of the other non-European regional blocs. Considering the fact that there is a high rate of intratrade in the European integration and the integration causes trade diversion we can come to the conclusion that Europe does not show the features of open regionalism (compared to Asia) and works upon the growth of the world economy fragmentation.

East Asia as a key part of the Asian region has so far marked a small growth of intratrade, or regional trade, as a result of its internal heterogeneity and its strong dependency on non-Asian markets. The fact led the Asian countries (including Japan) to the relatively consistent multilateralism, or relatively late start of closer economic integration in the long-term horizon. Only the ASEAN integration effort in 1990s and at the beginning of the new millennium meant closer inclination to regionalism. However, despite its certain increase the share of intratrade has remained low until now. For this reason there is absence of the strong trade diversion, at least in the key ASEAN countries.

ASEAN, as a certain core of the East Asia integration, keeps the shallow form of integration (a similar but looser form is followed by APEC). Thus, the ASEAN builds up wide less institutionalised co-operation within the framework of an enlarged free trade area (sometimes mentioned as ASEAN $+\mathrm{X}$ ). Therefore, among the world centres ASEAN fulfils best the characteristic of the open regionalism. Both small Asian countries and the two key countries of the region, China and Japan, remain strongly bound up with the other world centres as far as the volume of their trade is concerned. Thus, we can state that the relatively free links inside the region as well as bigger economic differences keep the region's structure rather diversified (fragmented) and, on the contrary, do not strengthen the fragmentation of the world economy as a whole.

The regional integration in the American continent is strongly affected by the hegemonic position of the U.S.A. Within their integration approach the United States combine their own security and political interests with the economic ones. Accordingly, they have changed the unilateral or multilateral approach for bilateral or regional solutions in their external economic relations. Unlike Europe, the U.S.A. do not enforce the deep integration to ensure their interests.

In the American region the disagreement has lasted with respect to the main integration structure solution. On the one hand, the NAFTA has created the free trade area formally, however, its goals being directed to the free movement of investment, services, government procurement as well as intellectual property right protection exceed that integration level. On the other hand in spite of the contingent declaration of a higher integration level, the other integration blocs in Latin America (e.g. MERCOSUR) keep having only looser economic relations. The U.S. attempt to create the wider common platform based on the NAFTA rules, FTAA, has wrecked for the time being. 
The U.S.A. enforce the proceeding of the integration toward FTAA in the continent using RTA enlargement to other countries ${ }^{14}$. However, in the meantime rather a hub-and-spoke structure is created strengthening the role of the U.S.A. In addition, the negotiation agenda of individual states is doubled by RTA's agenda (noodle bowl effect) in their effort to conclude other advantageous trade agreements with non-member states. The absence of a single regional negotiation mechanism multiplies the risk of the failure of intra-regional trade development (Tumbarello, 2007, p. 5) ${ }^{15}$. Then, there is relative fragmentation of the region reflecting those heterogeneous integration tendencies. The fragmentation is also supported by considerable differences in the economic level of the countries as well as in their social and political development. Not only do the differences exist between the U.S.A. (and Canada) and the rest of the region but also even inside the group of the Latin American countries.

In relation with the world economy measured through the share of region intratrade in total trade the American area appears more open than Europe though less than Asia. There are huge sub-regional differences between the NAFTA countries and the other RTAs. The NAFTA is more closed inclining to trade diversion. The other RTAs (e.g. MERCOSUR) have not showed that tendency distinctively and they make an effort to be bound up with the other world centres (the EU). The general impact of the American region on the world economy fragmentation or unity is uncertain as well as with respect to the potential rise of FTAA, although in this case econometric models do not predict the trade diversion rise.

We can summarise that there is the significant tendency to regionalism varying in its intensity in the main centres of the world economy which also influences differently their unity or coherence. The relatively high homogeneity of Europe, actual or potential, works rather on the global fragmentation compared to Asia, the trade structure of which is yet more regionalised, however open in general. Regarding the American area, crystallisation of the regional integration structure is still running there, and its impact on possible global fragmentation is uncertain.

It seems that even in the case of further growing regionalisation the following formal fragmentation of the world economy may not need to lead to such a closing of regions, which would cause substantial growth of trade diversion, or a substantial break of multilateral liberalisation.

14 See the concepts of additive or competitive liberalisation, which could be considered domino effect manifestations. E.g. in 2004 the United States - Central America - Dominican Republic Free Trade Agreement (CAFTA-DR) was signed between the U.S.A. and six countries of the Middle America.

15 Hub-and-spoke structure means that the strongest "central" country (hub) concludes individual agreements with a large number of small countries or a group of small countries (spokes), while trade restrictions remain among the small countries. Then spokes are marginalised compared to "centre" which has a free trade access to all those spokes. In that situation the hub is an economic winner to the detriment of the spokes getting dependent on the hub. Some authors find that approach typical namely for the U.S.A. in the American region. (Phillips, 2003, p. 2 and the next). 


\section{References}

AGHION, P.; ANTRÀS, P.; HELPMAN, E. (2004). Negotiating Free Trade. Working Paper No. 10721, Cambridge, MA, National Bureau of Economic Research.

AITKEN, N.D. (1973). The Effect of the EEC and EFTA on European Trade: a Temporal Cross-Section Analysis. American Economic Review, Vol. 63, pp. 881-891.

ANDRIANAMANJARA, S. (2003). On the Relationship between Preferential Trade Agreements and the Multilateral Trading System. Remarks for the PECC Trade Forum Meetings at the Institute for International Economics Washington, April 22. www.iadb.org/intal/foros/LAandriamananjara-paper.pdf.

ASEAN (2004). The Thirty Sixth ASEAN Economic Ministers Meeting Joint Media Statement. Jakarta: 3 September.

http://www.aseansec.org/16377.htm.

ASEAN (2004a). The Eighteenth Meeting of the ASEAN Free Trade Area (AFTA) Council. Joint Media Statement. Jakarta, 2 September.

www.aseansec.org/16349.htm.

ASEAN (2004b). ASEAN Secretary-General Interview by $21^{\text {st }}$ Century Business Herald Singapore. 11 October.

www.aseansec.org/16545.htm.

BALDWIN, R. (1993). A Domino Theory of Regionalism. Working Paper No. 4465, Cambridge, National Bureau of Economic Research, September.

BERGSTEN, F. C. (1996). Competitive Liberalization and Global Free Trade: A Vision for the Early $21^{\text {st }}$ Century. Working Paper 96-15, Institute for International Economics.

BHAGWATI, J. (1993). Regionalism and Multilateralism: An Overview. In De MELO, K., PANAGARIYA, A. (eds.). New Dimensions in Regional Integration. Cambridge, Cambridge University Press.

BHAGWATI, J.; PANAGARIYA, A. (2003). Bilateral Trade Treaties Are a Shame. Financial Times, July 13.

www.globalpolicy.org/globaliz/econ/2003/0716sharks.htm

BURFISHER, M. E.; ROBINSON, S.; THIERFELDER, K. (2003). Regionalism: Old and New, Theory and Practice. Invited paper presented at the International Conference „Agricultural policy reform and the WTO: where are we heading?“. Capri (Italy), June 23-26.

CIHELKOVÁ, E.; NEUMANN, P. (2002). Globalizace a regionalizmus: teorie a realita. In BERNÁŠEK, V. at all. Globalizační procesy ve světové ekonomice. Praha, Nakladatelství Oeconomica, pp. 29-54.

DIAO, X.; DÍAZ-BONILLA, E.; SHERMAN, R. (2003). Scenarios for trade integration in the Americas. Économie internationale, No. 94-95, 2003/2-3, pp. 33-51.

http://www.cairn.info/article.phd.

DIAO, X.; DÍAZ-BONILLA, E.; SHERMAN, R. (2002). Scenarios for trade integration in the Americas. TMD Discussion Paper No. 90, Washington, D.C., International Food Policy Research Institute, February.

http://www.cgiar.org/ifpri/divs/tmd/dp.htm. 
East Asia Economic Community: Prospects and Implications (2003): Keynote Speech of Pengian Mashor Pengian Ahmad, Deputy Secretary-General, ASEAN Secretariat. „ASEAN Plus Three - Perspectives of Regional Integration in East Asia and Lessons from Europe“. Seoul, 30 November - 1 December.

www.aseansec.org/15655.htm.

FISHLOW, A.; HAGGARD, S. (1992). The United States and the Regionalisation of the World Economy. Paris, Development Centre of the OECD.

FRANKEL, J.; WEI, S. (1993). Trade Blocks and Currency Blocks. NBER Working Paper No. 4335, Cambridge, MA, National Bureau of Economic Research.

GIRVAN, N. (1999). Globalization, Fragmentation and Integration: A Caribbean Perspective. Paper prepared for International Meeting on Globalization and Development Problems. Havana, January 18-22.

http://www.geocities.com/ColledgePark/Library/ 3954/girvan.pdf.

GRUBEN, W. C.; WELCH, J. H. (1994). Is NAFTA Economic Integration? Economic Review, Federal Reserve Bank of Dallas, Second Quarter.

HABERLER, G. (1964). Integration and Growth of the World Economy in Historical Perspective. American Economic Review, March.

HANSEN-KUHN, K. (2003). Alien Groups, Governments, Seek Scaled Back FTAA at Miami Ministerial. Foreign Policy in Focus, November 2003.

www.globalpolicy.org/globaliz/econ/2003/11scalebackftaa.htm.

HILAIRE, A.; YANG, Y. (2003). The United States and the New Regionalism/ Bilateralism. IMF Working Paper 03/206, October 2003.

www.imf.org/external/ pubs/ft/wp/2003/wp03206.pdf.

KOL, J. (1995). Bloc Formation, Fragmentation and Stability in the World Economy. The Hague, Scientific Council for Government Policy, September.

MORAIS, A. G.; BENDER, S. (2006). Trade Creation and Trade Diversion in MERCOSUR and NAFTA. Proceedings of the $34^{\text {th }}$ Brazilian Economic Meeting, No. 122, Brazilian Association of Graduate Programs in Economics.

http://ideas.repec.org/p/anp/en2006/122.htm.

ORME, W. A., Jr. (1998). Understanding NAFTA. Austin, University of Texas Press, 1998.

PANAGARIYA, A. (1994). East Asia: A New Trading System? Finance \& Development, Vol. 31, No. 1, March.

PETERSON, L. E. (2003). Pledging Allegiance to U.S. Foreign Policy. Rabble, July 18, 2003.

www.globalpolicy.org/globaliz/econ/2003/0721usbilat.htm.

PHILLIPS, N. (2003). Power and the Emerging Politics of Economic Governance in the Americas. Paper for presentation at the Conference „Building the Americas“, Montréal, 5-7 November.

REYES, R. A. (2005). Economic Cooperation Summitry: From Santiago to Vientiane. ASEAN Secretariat. www.aseansec.org/17094.htm. 
RIEDER, R. (2006). Playing Dominoes in Europe: An Analysis of the Domino Theory for the EU, 1962-2004. HEI Working Paper No. 11/2006, Geneva, Graduate Institute for International Studies, June.

SAPIR, A. (2001). Domino Effect in Western European Regional Trade 1960-1992. European Journal of Political Economy, Vol. 17, 2001, p. 377-388.

SCHWARTZ, A.; ZYSMAN, J. (1998). Reunifying Europe in an Emerging World Economy: Economic Heterogeneity, New Industrial Options, and Political Choices. Paper BRIEWP113, Berkeley Roundtable on the International Economy, University of California, Berkeley.

http://repositories.cdlib.org/cgi/viewcontent.cgi?article=10688 context=brie.

TUMBARELLO, P. (2007). Are Regional Trade Agreements in Asia Stumbling or Building Blocks? Implication for the Mekong-3 Countries. IMF Working Paper WP/07/53, March 2.

VINER, J. (1950). The Customs Union Issue. New York, Carnegie Endowment for International Peace, 1950.

WALL, H. J. (2002). Has Japan Been Left Out in the Cold by Regional Integration? Federal Reserve Bank of St. Louis, September/October.

WEINTRAUB, S. (2003). Lack of Clarity in U.S. Trade Policy. Issues in International Political Economy, No. 43, July. www.csis.org/simonchair/issues200307.pdf.

YI, S. (1996). Endogeneous Formation of Customs Union Under Imperfect Competition: Open Regionalism is Good. Journal of International Economics, Vol. 41, pp. 153-177.

\title{
Fragmentace versus jednota světové ekonomiky
}

\section{Pavel Neumann}

\begin{abstract}
Abstrakt
Článek pojednává o vývoji fragmentace a jednoty světové ekonomiky s ohledem na její hlavní centra (Evropa/EU, východní Asie, Amerika). Z pohledu probíhající multilaterální liberalizace se světová ekonomika formovala po druhé světové válce zprvu jako relativně jednotná. Avšak po zesílení regionalizace v 90. letech se silnější fragmentace projevuje jako přirozený prvek globalizace světové ekonomiky v podobě. tzv. nového regionalismu. Z hlediska teorie lze fragmentační proces vysvětlit Vinerovou teorií celní unie, později i dominovou teorií regionalismu rozvíjenou řadou autorů. Pokud jde o jednotlivá centra, Evropa, navzdory současné diferenciaci je jednotnější než jiné regiony. Avšak díky svému konceptu hluboké integrace, odklonu obchodu pramenícího z vysokého stupně interního obchodu, Evropa přispívá spíše ke světové fragmentaci. Východní Asie představovaná ASEAN setrvává u mělké integrace, která spolupracuje s nečlenskými zeměmi. Tato skupina nyní nejlépe splňuje charakteristiku otevřeného regionalismu, jenž neposiluje fragmentaci světové ekonomiky. Americká oblast je dosud relativně fragmentovaná navzdory snaze USA vytvořit širší zónu integrace po vzoru NAFTA. Americký region se jeví
\end{abstract}


více otevřený než Evropa vzhledem k podílu intratrade, avšak jeho integrační struktura se dosud vyvíjí, s nejistým dopadem na řešení rozporu mezi světovou fragmentací a jednotou.

Klíčová slova: světová ekonomika, fragmentace, jednota, regionalismus, multilateralismus, regionální obchodní dohody, intratrade.

\title{
Fragmentation versus Unity of the World Economy
}

\begin{abstract}
The article deals with fragmentation and unity prospects of the world economy with respect to the role of its main centres (Europe/EU, East Asia, America). From the view point of the process of the running multilateral liberalisation the world economy was formed as relatively unified at first after World War II. However, regionalisation intensified in 1990s and since then stronger fragmentation has become a natural element of the world economy globalization as ,new regionalism”. Theoretically, the fragmentation process can be explained by Viner's customs union theory as well as later by the regionalism domino theory developed by many authors. Concerning the role of individual centres, despite its present differentiation, Europe (EU), is more unified than the other regions. However, with its deep integration concept and trade diversion stemming from a high intratrade rate, Europe contributes rather to the world fragmentation. East Asia represented by ASEAN keeps still sticking to the shallow integration, co-operating with non-member partners. The group represents best the open regionalism characteristics, currently not strengthening the world economy fragmentation. The American area remains still relatively fragmented despite the U.S. effort to create a wide integration zone similar to NAFTA. The American region appears more open than Europe with respect to the intratrade share, nevertheless, its integration structure is still in progress; and its impact on the solution of the world economy fragmentation-unity dilemma is uncertain.
\end{abstract}

Key words: world economy, fragmentation, unity, regionalism, multilateralism, regional trade agreements, intratrade.

JEL classification: G30 